DOI: 10.32370/IA_2021_06_10

\title{
Problems of Metaphorization in Modern Directing Theater
}

\author{
Ivashchenko Irina Vitalievna, \\ Associate Professor, Honored Artist of Ukraine, \\ Kiev National University of Culture and Arts, \\ Kiev, Ukraine
}

\begin{abstract}
Metaphorization as a universal method of replenishing lexical means of expression and creating a complex semantic structure of the production is studied; the types of theatrical metaphors in the context of tendencies of modern directing theater are analyzed; found that primarily metaphorization depends on the goals and objectives of the director, which are focused on filling conceptual gaps and creating a pragmatic effect in the viewer - this leads to predicting understanding of metaphor and appeal to image-associative complexes of current realities.

It is revealed that in the modern director's theater there is a process of metaphorization of the surrounding world, in which new metaphorical models appear, and traditional ones are updated and actualized, constantly absorbing new meanings.

Within one or another director's theater, there is a variety of activity of appealing to basic metaphors, changing key metaphors and generating new submodels.
\end{abstract}

Key words: metaphor, metaphorization, director's theater, artistic image, association, concept of performance.

Актуальність дослідження. Метафора як художній образ $є$ формою узагальненого відображення та пізнання дійсності, створеної на основі образного мислення, що являє собою органічну єдність чуттєво-споглядальних та раціональноабстрактних форм пізнання - це інструмент, за допомогою якого режисер може донести важливу для нього інформацію.

Кожному режисеру властива специфічна метафорична мова - у контексті специфіки сучасного театрального мистецтва вона знаходить виявлення у постановках, сповнених каскадом метафор, або в розширенні метафори до живих метафоричних картин, що сприяють вираженню головної концепції сценічного твору (зазвичай концептуальні метафори використовуються для створення картини світу, в якому діють персонажі) або є суто образотворчими. У постановках багатьох сучасних театральних режисерів здійснюється спроба за допомогою метафори як особливого типу світосприйняття визначити ментальну цілісність періоду культурно-історичної доби, відтворити портрет доби та зафіксувати дух часу. За характером такої метафори та їі сенсової і соціальної спрямованості можна зрозуміти менталітет суспільства у певний 
період його розвитку. Метафора передає стан доби, оскільки каталізатором до іiі формування є фактор особливої емоційної напруги як відображення часу.

Специфіка функціонування метафори в творчості театральних режисерів кінця XX - початку XXI ст. дозволяє не лише констатувати суттєву роль метафоричного начала в постановках сучасного театру, але й підводять до необхідності детального вивчення даної проблеми.

Аналіз публікацій. Як універсальне явище культури метафора досліджується різними напрямами сучасної наукової думки, а вчені вбачають в ній ключ до розуміння «основ мислення та процесу створення не лише національного специфічного бачення світу, але і його універсального образу» [1, с. 672]. Водночас у вітчизняному академічному вимірі бракує наукових досліджень та публікацій, присвячених питанню метафоризації в театрі кінця XX - початку XXI ст. Аналіз наукової літератури засвідчив, що здебільшого вітчизняними мистецтвознавцями і театрознавцями висвітлено окремі аспекти звернення сучасних режисерів до метафори як форми узагальненого відображення та пізнання дійсності, створеної на основі образного мислення. Наприклад, О. Чирков у монографії «Метафоричний театр Петра Авраменка» розглядає постановки П. Авраменка в контексті поетики створеного ним театру [8]; В. Пацунов у науковій статті «Альтернативний сценічний простір як ефективний чинник оновлення сценографічної лексики» [6] та С. Триколенко в публікації «Поєднання реалістичних та метафоричних елементів сценографії на прикладах вистав великої сцени» [7] проблематику метафоризації досліджують в контексті головних тенденцій сценографії; Р. Никоненко в дослідженні «Пластична режисура в українському театральному мистецтві кінця XX - початку XXI століття» [5] розглядає метафоричне вираження певної ідеї в контексті асоціативного змісту та пластичного мотиву композиції вистави на прикладі постановок А. Жолдака, Д. Богомазова та I. Волицької.

Окремих наукових праць, предметом дослідження яких стала метафоризація в режисерському театрі на сучасному етапі розвитку соціомистецького простору в теорії театрального мистецтва не вистачає. Практика сучасного режисерського театру значно випереджає теоретичне осмислення багатьох аспектів проблематики, пов’язаних із процесом метафоризації, що актуалізує здійснення мистецтвознавчого дослідження в означеному напрямі. 
Мета статті - виявити особливості процесу метафоризації в контексті специфіки сучасного режисерського театру.

Виклад основного матеріалу. Х.-Т. Леман - один із найвідоміших сучасних театрознавців, характеризує режисерський театр XXI ст. як постантропоцентричний, що обходиться без актора як центральної фігури, а якщо і включає їі, то лише як актант один із елементів постпрострової структури. Це відповідно призводить до виникнення «певних естетичних утворень, що можуть утопічним чином указувати на можливу альтернативу антропоцентричному ідеалу підкорення природи. Коли людські тіла поєднуються з предметами, тваринами та енергетичними лініями в певну реальність... саме театр вперше дає нам можливість уявити себе реальністю, відмінною від реальності людини, яка перемагає природу» [3, с. 131-132].

На думку Ю. Шатіна, на сучасному етапі можна говорити про режисерський театр як про сформовану систему, що успішно функціонує в світі та осмислено протистоїть акторському театру. Дослідник наголошує на тому, що основними властивостями режисерського театру є:

- максимальна екстеріоризація театрального простору, що прагне в ідеалі до тотального охоплення простору світу (на відміну від традиційного театрального простору, в якому завіса є семантичною межею, що відділяє театр від буденності, режисерський театр охоплює нові зони, в яких театром стає все);

- протиставлення максимальній естеріоризації театру максимальної інтеріоризації центральної точки вистави, своєрідного пунктумума (за Р. Бартом) імперії знаків, що в своєму різноманітті створюють семотичний контрапункт, який сполучає річ з актором або надмаріонетку - актора - $з$ річчю;

- відмова від домінування драматичного тексту та слова: на тлі неконтрольованого потоку інформації людина поступово втрачає здатність виробляти нові сенси засобами наявних слів та знаходити сенс у наявних словарних конструкціях;

- перформативна природа.

Відповідно сучасний режисерський театр пропонує співіснування та одночасно боротьбу двох різних моделей сприйняття та сенсотворення, що умовно можна означити як феноменологічне тіло вистави, з одного боку, та як тіло семіотичне, з іншого [9, с. 19]. 
Театрознавче визначення метафори включає в себе комплекс особливостей застосування, ii реалізації та домінування в сценічному творі. Метафора є формою узагальненого відображення та пізнання дійсності, створеної на основі образного мислення, що являє собою органічну єдність чуттєво-споглядальних та раціональноабстрактних форм пізнання. Це інструмент, за допомогою якого режисер може донести важливу для нього інформацію. В межах даного дослідження ця позиція стала визначальною для розуміння функції метафори в сучасному режисерському театрі. Метафоризація розуміється нами за Д. Лотте як процес створення режисером складної семантичної структури постановки на базі висхідних одиниць [4, с. 268].

Відомий лінгвіст та семіотик В. Нет наголошує, що в більшості традиційних визначень метафори з'являються дві концепції: подібність та перенесення [13, p. 128]. Метафора - це фігура мови, в якій слово або фраза, що означають об’єкт або дію одного виду, використовуються замість другого об’єкта або дії на основі подібності [12, p. 925]. Ідея перенесення проявляється в етимології слова «метафора» - в перекладі з грецької воно означає «перенесення з одного місця в інше» [12, р. 925], при цьому одне з цих «місць» створено сферою буквального значення, а друге - сферою переносного значення.

Існує чотири стадії метафоричності метафори (або ступеня ії інтенсивності), що відрізняються своєю оригінальністю та новизною, а також відчутністю контрасту між переносним і буквальним значенням: обидва пов'язані порівнянням (наприклад, «полум'я кохання»); якщо напруга між буквальним і переданим сенсом зникає, метафора перетворюється на частину повсякденного життя (наприклад, «дно котла»); якщо висхідне буквальне значення зникає, з'являються непрозорі метафори («аутентичний» - від грецького «authentēs» - хтось, хто все робить сам); мертві метафори, буквальне значення яких відомо лише етимологу [12, p. 791].

Відповідно до специфіки сучасного режисерського театру виділяють:

- метафори оформлення (метафори, що означені концепцією сценографії або іiі елементами);

- метафори пантоміми (метафори, що означені виражальною мовою рухів, жестів та міміки актора); 
- метафори мізансцени (у цьому випадку мізансцена в цілому репрезентована як узагальнений образ, як знак певної ідеї);

- метафори в акторській грі (багатомірний образ створюється акторським наслідуванням реальної людини, тварини або предмету);

- метафори-алегорії (зображення відстороненої ідеї засобами конкретного репрезентованого образу).

Метафора - це іконічний знак, оскільки іконічний знак являє об'єкт на основі схожості між знаком і тим, що він означає [13, p. 128], проте не всі іконічні знаки є метафорами. Одна з форм театру - так званий театр «ілюзії життя» - примушує глядача сприймати виставу як безпосередню картину світу, репрезентовану драматургом; інші пропонують метафоричне зображення зі спільною структурною схожістю між знаком та об'єктом.

Знак створюється та розуміється як метафора лише тоді, коли творець та той, хто сприймає знак осмислюють напругу між буквальним та переносним значенням знаку (наприклад, зелене покриття сцени в постановці роману А. Упіта «Земля зелена» може сприйматися як метафорична заміна зелених полів на основі однієї спільної властивості - зеленого кольору).

Дослідники наголошують, що театр наділений невичерпними візуальними можливостями для створення метафор, проте в постановка сучасного режисерського театру активно використовується протилежна техніка - так звана редукція метафор (зведення складного до простого), коли лінгвістичні метафори візуалізуються в образах, що відміняють передачу значення, повертаючись до буквального значення. У власній сценічній образності редукцію метафори використовує один із найвідоміших європейських режисерів Е. Някрошюс. Наприклад, в одному з епіздів вистави «I довше віку триває день» за твором Ч. Айтматова (1983 р., Литовський державний молодіжний театр) метафора «душевний біль», що означає нерозділене кохання, зводиться режисером до фізичного серцевого нападу. А у виставі «Моцарт і Сальєрі. Дон Жуан. Чума» (за «Маленькими трагедіями» О. Пушкіна, 1994 р., Литовський міжнародний фестиваль «Лайф») лінгвістична метафора «запалити полум'я пристрасті» візуалізується Доном Хуаном та Анною, які кидають один в одного запалені сірники, що на якусь мить спалахують і згасають, лишаючи лише стрічку диму та запах сірки. Тут режисер прагне 
показати, що кохання схоже на полум'я, оскільки вони обидва гарячі, обидва згасають і лишають після себе сліди у вигляді диму або спогадів. На думку дослідників, таке повернення до буквального значення корелюється 3 точки зору позитивізму (неоемпіризму), відповідно до якої відчуття є джерелом та метою пізнання: всі наукові твердження в філософії, природознавстві та інших науках повинні підлягати емпіричній перевірці через органи чуття, а якщо це не так, їх необхідно знизити до рівня, на якому вони можуть бути перевірені [11, p. 177]. Тобто наші уявлення про світ або є сенсорним сприйняттям, або пов'язані з таким сенсорним сприйняттям. Один із найвідомших мислителів XX ст., засновник аналітичної філософії, австро-англійський філософ Л. Вітгенштейн у ранніх працях дотримувався аналогічної точки зору: «якщо слова у виразі не пов'язані з об'єктами, речення, яке ми можемо побудувати з цих слів, нічого не буде виражати. Як і в картині - якщо точка на полотні не пов'язана з точками в просторі, тобто зі структурами, що існують в реальності, картина, яку художник зможе намалювати, нічого не виразить» [14, p. 41]. Провідний реформатор театру А. Арто, який хотів створити неможливе - мову, що не лише б виражала його думки, але й надихала його думки [10, pр. 121-123] - підкреслює роль досвіду, необхідність прагнути до тих художніх виражень, що дозволять перевірити через органи чуття, чи відповідають вони структурам, існуючим у реальності.

На думку дослідників, актуальним є питання чи сприяє скорочення переносу розкриттю художнього задуму і яким чином. Литовська дослідниця В. Чакаре наводить приклад використання метафори в постановках Ю. Рійнієкса «Сімка з Маленії» (1994 р.) та М. Груздова «Анна Кареніна» Л. Толстого (2011р.). В одному з епізодів вистави «Сімка з Маленії» звучить пісня зі словами «як добре, так добре на землі мого батька, заяць може петляти, а тетерів - барабанити», а по сцені біжить актор у заячій шапцівушанці з ласо в руках, яким він крутить над головою. Фраза «заяць може петляти» має переносне значення «їхати, бігти, об'їзджати», а режисер відновлює буквальне значення. Проте, на думку В. Чакаре, цю метафору можна було візуалізувати інакше, наприклад, змусити зайця в'язати [11, р. 179]. У постановці М. Груздова «Анна Кареніна» Л. Толстого (2011 р.) режисер візуалізує метафору «падша жінка» (развратна жінка, прелюбодійка): суспільство бачить Анну як «падшу жінку», і режисер акцентує на цьому, змушуючи героїню кілька разів впасти зі стільця та під час прогулянки. 
Відмінність цих прикладів, на думку дослідниці, полягає в тому, що коли метафора зводиться до їі буквального значення, означуване лишається незмінним: означені зміни ліквідують дистанцію між двома пов'язаними реальностями. У випадку «петлі» - при відновленні буквального значення важливим є момент подиву: візуалізація буквального значення $\epsilon$ новаторською i парадоксальною, оскільки як висхідний матеріал використовується зобарження зі стабільним метафоричним значенням. Таким чином, спектр сенсів у виставі розширюється, тобто пропонується нова інформація про поведінку зайця. Але падіння Анни Кареніної зі стільця передбачуване: воно лише підтверджує сказане у виставі іншими способами, а показане як реалістичний рух, який можна інтерпретувати в контексті повсякденної поведінки, що не руйнує сприйняття і відповідно не розвиває здібність бачити під іншим кутом [11, p. 179].

Через метафоричність концептуальної системи людини, метафора є одним із основних механізмів, що забезпечують в свідомості людини структурування реального світу та накопиченого нею досвіду. На думку Дж. Лакофа та М. Джонсона [2, с. 392415], концептуальна система людини вміщує певний набір конвенційних метафоричних проекцій, що використовуються нею несвідомо, автоматично - це так звані концептуальні (або базові, ключові, ціннісно-прототипні) метафори як певна фундаментальна ідея бачення світу. Дослідники наголошують, що антропоморфна, соціальна, природна та артефактна метафори - найважливіші в розумовій та вербальній діяльності людини через те, що вони формують концептуальні структури глобального рівня - когнітивні моделі, що базуються на фізичному та культурному досвіді людини і є основою когнітивного моделювання світу.

Дослідження виявило, що навіть натуралізована метафора зберігає потенційно вибудований образ, що непомітний в повсякденному використанні. Образність полягає в лінгвістичній впевненості, оскільки лінгвістичний знак створюється та розуміється як метафора лише якщо той, хто говорить (режисер) і той, хто слухає (глядач) осмислюють напругу між буквальним і переносним значенням знаку. Проте оскільки кожен глядач розпізнає різноманітні метафори по-різному, для того, щоб оцінити образ виступу як метафору або скорочення метафори, необхідно розуміти культурний контекст, зображення має сприйматися в загальній системі знаків виступу, окрім того глядач має володіти вербальною і невербальною театральною мовою. 


\section{Висновки}

В сучасному режисерському театрі відбувається процес метафоризації навколишнього світу, в якому виникають нові метафоричні моделі, а традиційні оновлюються та актуалізуються, постійно вбираючи в себе нові сенси.

У межах когнітивної парадигми досліджень метафори в сучасному режисерському театрі важлива роль належить кодуванню інформації та іiї трансформації через концептуальні галузі унаочненого ментального простору на приховане. Тобто, як бачення одного об'єкта засобами іншого, воно здійснюється структуруванням ментального знання або його репрезентацією у візуальній формі. При цьому метафора належить не до окремих ізольованих об'єктів постановочного тексту, а до складних розумових просторів, що співвідносяться зі більш простими і конкретними. Метафори структурують глядацьке сприйняття, мислення та дії, як конструктивний елемент, що організовує та впорядковує понятійну систему людини. Креативна природа метафори таким чином зумовлює їі участь в процесі формування нового сприйняття, осмислення та відображення об'єктивної реальності.

У межах того чи іншого режисерського театру спостерігається різноманітна активність звернення до базових метафор, зміни ключової метафори та породження нових субмоделей. Основною ознакою метафори сучасного режисерського театру можна вважати новаторство, оскільки метафора $\epsilon$ реакцією на зміни: оновлення концептуальної метафори досягається завдяки динаміці іiі структурно-семантичних зв’язків (шляхом актуалізації режисером відомих асоціативних співвідношень або їх деформації, а також виникнення нових).

\section{References}

1. Arutyunova, N. D. (1990). Metaphor and discourse. Metaphor theory. Moscow.

2. Lakoff, J., Johnson, M. (1990). The Metaphors We Live By. Metaphor theory. Moscow: Progress, pp. 387-415.

3. Lehman, H.-T. (2013). Post-dramatic performance. Moscow.

4. Lotte, D. S. (1968). How to work on term inology. Moscow.

5. Nikonenko, R. M. (2021). Plastic directing in the Ukrainian theatrical art of the end of the XX - the beginning of the XXI century. Abstract of Ph.D. Kyiv : Kyiv National University of Culture and Arts. 
6. Patsunov, V. (2018). Alternative stage space as an effective factor in updating the scenographic vocabulary. Scientific notes of Ternopil National Pedagogical University. V. Hnatyuk. Series: Art History, no. 1, pp. 211-216.

7. Trikolenko, S. (2017). Combination of realistic and metaphorical elements of scenography on the examples of performances of the big stage. Theory and practice of design. Art History, Issue 12, pp. 3-12.

8. Chirkov, O. (2012). Metaphorical Theater of Peter Avramenko. Zhitomir: Ruta.

9. Shatin, Y. (2017). Contemporary theory of drama and poetics of director's theater. Theater and drama: the aesthetic experience of the era, no. 4, pp. 16-24.

10. Artaud, A. (1991). Oriental and Western Theatre. In Artaud on Theatre, edited by Claude Schumacher. London: Methuen Drama.

11. Čakare, V. (2013). Performing metaphors: attempts at positivist reduction of figurative meaning in contemporary Latvian theatre, 1990-2011. In : Text in Contemporary Theatre: The Baltics within the World Experience. Edited by Guna Zeltina with Sanita Reinsone. Cambridge Scholars Publishing, pp. 175-181.

12. Guralnik, D. B. (eds.). (1968). Webster's New World Dictionary of the American Language. Cleveland and New York: The World Publishing Company.

13. Nöth, W. (1995). Handbook of Semiotics. Bloomington and Indianapolis: Indiana University Press.

14. Wittgenstein, L. (2005). Tractatus Logico-Philosophicus. Translated by Charles Kay Ogden. New York: Routledge.

\section{Translation of the References to the Author's Language}

\section{Список використаних джерел:}

1. Арутюнова Н. Д. Метафора и дискурс. Теория метафоры. Москва, 1990.

2. Лакофф Дж., Джонсон М. Метафоры, которыми мы живем. Теория метафоры. Москва : Прогресс, 1990. С. 387-415.

3. Леман Х.-Т. Постдраматический спектакль. Москва, 2013. 308 с.

4. Лотте Д. С. Как работать над терм инологией. Москва, 1968. 76 с.

5. Никоненко Р. М. Пластична режисура в українському театральному мистецтві кінця XX - початку XXI століття: автореферат дис. канд. мистецтвознавства :26.00.01 / Київський національний університет культури і мистецтв. Київ, 2021. 21 с.

6. Пацунов В. Альтернативний сценічний простір як ефективний чинник оновлення сценографічної лексики. Наукові записки Тернопільсткого національного педагогічного університету ім. В. Гнатюка. Серія : Мистецтвознавство, 2018. № 1. С. 211-216. 
7. Триколенко С. Поєднання реалістичних та метафоричних елементів сценографії на прикладах вистав великої сцени. Теорія і практика дизайну. Мистецтвознавство, 2017. Вип. 12. С. 3-12.

8. Чирков О. Метафоричний театр Петра Авраменка. Житомир : Рута, 2012. 198с.

9. Шатин Ю. (2017). Современная теория драмы и поэтика режиссерского театра. Театр и драма: эстетический опыт эпохи. 2017. № 4. С. 16-24.

10. Artaud A. Oriental and Western Theatre. In Artaud on Theatre, edited by Claude Schumacher. London: Methuen Drama, 1991. 210 p.

11. Čakare V. Performing metaphors: attempts at positivist reduction of figurative meaning in contemporary Latvian theatre, 1990-2011. In : Text in Contemporary Theatre: The Baltics within the World Experience. Edited by Guna Zeltina with Sanita Reinsone. Cambridge Scholars Publishing, 2013. pp. 175-181.

12. Guralnik D. B. (eds.). Webster's New World Dictionary of the American Language. Cleveland and New York: The World Publishing Company, 1968. 1724 p.

13. Nöth W. Handbook of Semiotics. Bloomington and Indianapolis: Indiana University Press, 1995. 576 p.

14. Wittgenstein L. Tractatus Logico-Philosophicus. Translated by Charles Kay Ogden. New York: Routledge, 2005. 226 p. 